\title{
Does Big Data Analytics Enhance Sustainability and Financial Performance? The Case of ASEAN Banks
}

\author{
Qaisar ALI ${ }^{1}$, Asma SALMAN ${ }^{2}$, Hakimah YAACOB ${ }^{3}$, Zaki ZAINI $^{4}$, Rose ABDULLAH ${ }^{5}$ \\ Received: April 07, 2020 Revised: May 10, 2020 Accepted: June 08, 2020
}

\begin{abstract}
This study analyzes the key drivers (commitment, integration of big data, green supply chain management, and green human resource practices) of sustainable capabilities and the influence to which these sustainable capabilities impact the banks' environmental and financial performance. Additionally, this study analyzes the impact of green management practices on the integration of big data technology with operations. The theory of dynamic capability was deployed to propose and empirically test the conceptual model. Data was collected through a self-administrated survey questionnaire from 319 participants employed at 35 banks located in six ASEAN countries. The findings indicate that big data analytics strategies have an impact on internal processes and banks' sustainable and financial performance. This study indicates that banks committed towards proper data monitoring of its clients achieve operational efficiency and sustainability goals. Moreover, our results confirm that banks practising green innovation strategies experience better environmental and economic performance as the employees of these banks have received advance green human resource training. Finally, our study found that internal and external green supply chain management practices have a positive impact on banks' environmental and financial performance, which confirms that ASEAN banks contributing in reduction of environmental impact through its operations will ultimately experience increased financial performance.
\end{abstract}

Key Words: Sustainability, ASEAN, Banks, Big Data Analytics, Financial Performance, Green Management

JEL Classification Code: E58, G21, Q5

\section{Introduction}

United Nations'2030Agenda for sustainable development and the global commitment to leave no one behind requires

${ }^{1}$ First Author. Faculty of Islamic Economics and Finance, University Islam Sultan Sharif Ali, Brunei Darussalam. Email: aliqaisar21@gmail.com

${ }^{2}$ Corresponding Author. Department of Accounting, Finance and Economics, College of Business Administration, American University in the Emirates (AUE) [Postal Address: Dubai International Academic City, Block 6 \& 7, United Arab Emirates] Email: asma.salman@aue.ae

${ }^{3}$ Faculty of Islamic Economics and Finance, university Islam Sultan Sharif Ali, Brunei Darussalam. Email: hakimahunissa@gmail.com

${ }^{4}$ Faculty of Islamic Economics and Finance, university Islam Sultan Sharif Ali, Brunei Darussalam. Email: zaki.zaini@unissa.edu.bn

${ }^{5}$ Faculty of Islamic Economics and Finance, university Islam Sultan Sharif Ali, Brunei Darussalam. Email: rose.abdullah@unissa.edu.bn

(c) Copyright: The Author(s)

This is an Open Access article distributed under the terms of the Creative Commons Attribution Non-Commercial License (http://Creativecommons.org/licenses/by-nc/4.0/) which permits unrestricted noncommercial use, distribution, and reproduction in any medium, provided the original work is properly cited. collecting, processing, and disseminating an unprecedented amount of data, including disaggregated data, for effective policy design, monitoring, and evaluation of progress (United Nations Report, 2019). The advent of big data (BD) has brought solace for humans and societies in numerous ways; especially, modern-day uncertainties confronted by human beings can effectively be reduced using BD (Allam, 2020). BD is going to stay, however, its environmental and social $(E \& S)$ consequences and the sustainability of BD needs further investigation. Corbett (2018) contends that the revelation of $\mathrm{BD}$ revolution has created new opportunities by increasing the awareness of E\&S impacts on supply chain and the concomitant potential to improve along these dimensions.

BD potentially impacts the businesses that warrant an analysis of the implications vis-à-vis organizational response, prospects, and challenges of environmentallysustainable business operations (Seles, de Sousa Jabbour, Jabbour, de Camargo Fiorini, Mohd- Yusoff, \& Thome, 2018). The traditional methods to acquire, access and analyze BD have become obsolete as these methods do not fit with 
the modern-day requirements of processing BD (Hampton, Strasser, Tewksbury, Gram, Budden, \& Batcheller, 2013). Nonetheless, firms' internal environment such as competencies and internal progressions through which BDAs can be used to develop strategies targeted to achieve higher performance remain unexplored. Additionally, most of the studies on enhancing sustainable capabilities (SCs) through BDAs concentrate on the manufacturing industry (Jabbour \& de Sousa Jabbour, 2016; Amui, Jabbour, de Sousa Jabbour, \& Kannan, 2017). There exists a dearth of studies on enhancing SC through BDAs despite the significance of the finance sector in developing post-2015 development agenda highlighted in the World Bank's Billions to trillions report (WWF Sustainable Finance Report, 2017).

Intriguingly, a firm is unable to develop SCs without assimilating the effective management of $\mathrm{BD}$ along with GHRM and green supply management (GSCM) (Amui, Jabbour, de Sousa Jabbour, \& Kannan, 2017). The existing studies on SCs of banks focus on customer perception of bank's corporate social responsibility initiatives, trustworthiness, and staff expertise as an instrument of SC (Pereze \& Bosque, 2015; Zimmermann, 2019). Additionally, current literature on sustainability has identified significant gaps, which are an obstacle in becoming a sustainable bank through corporate commitment and GSCM (Amui, Jabbour, de Sousa Jabbour, \& Kannan, 2017; Govindan, Sarkis, Jabbour, Zhu, \& Geng, 2014). The fact that ASEAN banks are less conducive to sustainability efforts as compared to European and other Western banks, and the lack of common matrices to measure sustainability in the finance sector also requires deep analyses of the idea presented in this study (World Economic Forum, 2019).

In this study, we propose that, through the integration of resources for developing SCs, banks can maximise sustainable performance, which entirely concentrates on bank's commitment to corroborate sustainable initiatives and $\mathrm{BD}$ management at operational and strategic levels. It is achievable by adopting a comprehensive and feasible process by policymakers to guarantee returns on investment in BD projects (Acharya, Singh, Pereira, \& Singh, 2018). This study augments the past studies on developing SCs in manufacturing sector such as Jabbour and de Sousa Jabbour (2016), Jackson, Renwick, Jabbour, and Muller-Camen (2011), Singh and El-Kassar (2019) and finance sector such as Zimmermann (2019), Pereze and Bosque (2015). In particular, this study investigates the subsequent questions;

- How do banks' SCs established on their commitment and resulting in the integration of BDT, GHRM practices, and GSCM improve environmental and operational performance of banks?
- What is the extent of GHRM practices to influence the integration of BDT within the bank's processes to strengthen the relationship between internal and external operations, and how does this impact on banks' sustainable performance?

The remaining paper proceeds as follows: Section 2 empirically reviews the literature and the underlying theoretical framework to develop the conceptual model and hypotheses of this study. Section 3 covers the adopted research methodology. Section 4 discusses the findings and results. Lastly, Section 5 presents the discussion and conclusion along with implications, limitations and suggestions for future studies.

\section{Literature Review}

\subsection{Big Data Analytics (BDAs)}

The literature defines it as the 'creation of new technologies and architectures designed to economically extract value from a large volume of data by capturing high velocity, discovery and/or analysis (Mikaleaf, Pappas, Krogstie, \& Giannakos, 2018). BDAs have attracted the attention of policymakers over the years to direct organizational decision-making (McAfee, Brynjolfsson, \& Davenport, 2012). A large number of firms have accelerated their BDAs initiatives to gain a critical insight into achieving competitive advantage. Practitioners and scholars have categorised BDAs as a prospective frontier for innovation, competition, and productivity (Manyika, Chui, Brown, Bughin, Dobbs, \& Roxburgh, 2015). However, some regarded it as a revolution that will transform the way of living, working, and thinking. Pertaining to the expansion of data volume, velocity, and variety, numerous efforts were made to store, analyze and visualize the data. Whereas, empirical evidence on the impact of BDAs on sustainable performance in the finance sector and the mechanism through which it helps to achieve competitive advantage for banks is still at a rudimentary state (Wamba, Gunasekaran, Akter, Rameshwar, Stephen, \& Childe, 2017). This is surprising following the narrative that corporates these days surge to venture in the area of BDAs (Mikaleaf, Krogstie, Pappas, \& Pavlou, 2019).

\subsection{Navigating BDAs in the Financial Sector}

BDAs emergence transformed the corporates production and operation modes. Numerous large firms aim to develop SCs through BDAs to achieve market competitiveness for its survival (Jun, 2019). BDAs help firms in using advance analytical skills to obtain quality information from BD, which enables firms to achieve higher operational efficiency 
and sustainable performance. BDAs assure superior performance for the organizations' genuine commitment. According to Mckinsey \& Company's Global Banking Report (2018), corporations that are analytically more driven experience three times higher growth as compared to the less driven competitors. The banking industry is among the pioneers of leveraging BDAs among all other industries such as pharmaceuticals, insurance, energy, manufacturing, and agriculture. Yet, the banking industry is unable to fully embed BDAs into its culture, decision processes, and business operations (Mckinsey \& Company Global Banking Report, 2018).

BDAs have become an essential tool for the banking industry in the detection of fraud and prevention of financial crime, credit risk management, and marketing purposes. Banks these days are shifting their business models from product-centric to customer-centric, which were achieved through BDAs. For example, one of the largest SingaporeMalaysia banks, the Overseas Chinese Banking Corporation (OCBC), has successfully analyzed historic customer data to determine their preferences (IBM Global Business Services Report, 2013). BDAs are also playing a significant role in financial inclusion, micro-financing and analyzing the creditworthiness of customers by processing structured and unstructured consumer data gathered from channels (The ASEAN Post, 2020).

\subsection{SCs of ASEAN Banks through BDAs}

The socio-economic livelihood of 650 million people in ASEAN countries is at considerable risk due to climate change, which is projected to result in a loss of around 6.7 percent of regional GDP by 2100 (WWF Sustainable Finance Report, 2017). The E\&S risks in the ASEAN region have reached an alarming level. For example, Southeast Asia only emits $12 \%$ of the global greenhouse gas due to large scale usage of fossil fuels (International Environment Agency, 2015). The social impacts in ASEAN could lead to one billion migrants in Asia Pacific, 13 million to 94 million people affected due to floods in South Asia, and 100 million people affected due to decline in coral reef fisheries (WWF Sustainable Finance Report, 2017).

ASEAN banks use BDAs to develop sustainable finance regulations, guidelines, and strategies to suggest banks to consider E\&S issues. A few banks in ASEAN have employed BDAs to analyze specific E\&S risks that might impact customers and also clearly address sustainability issues. ASEAN banks have also deployed BDAs to strengthen their corporate governance structure to harmonize sustainable finance regulations across the region. Banks establish formal and informal channels to engage stakeholders and transparently communicate sustainability goals, action, best practices, performance data, and sustainability matrices at regular intervals, which enhance the visibility and credibility of a bank (UNEP Finance Initiative, 2016).

\subsection{Theoretical Model and Hypotheses}

This study is built upon the theoretical lens of dynamic capabilities (DCs), which investigates the internal and external competency changes through integration and reconfiguration (Teece, Pisano, \& Shuen, 1997). Managers handling operations of non-linear market face organizational challenges that heavily rely on existing knowledge and past experience (Argote, 2012). This leads to innovation and urges leaders to recognise their knowledge through realistic data, cross-functional affiliations, and other available communication tools, which can be used to influence the sustainable development in a region (Nurlanova, Akedil, Omarov, \& Satpayeva, 2020).

The assimilation, acceptance, and routinization of BD influence bank's operational activities, enhance stakeholders' interest in such technologies, and strengthen bank's governance system through integration of the technologies (Gunasekaran, Papadopoulos, Dubey, Wamba, Childe, \& Hazen, 2017). Similarly, environmental disclosure information help corporations in engaging stakeholders and improve their social responsibility (Nguyen, Nguyen, Nguyen, Le, \& Nguyen, 2020). The assimilation process is concerned with the bank's integration and extension of its processes and practices to achieve its goals and objectives (Hazen, Overstreet, \& Cegielski, 2012). BDAs deploy distinct capability of information processing for value creation to enhance the competitive advantage of a bank and seek top management support and commitment. The proceeding argument leads to the development of following hypothesis:

H1. Bank commitment positively impacts on acceptance, routinization, and assimilation of $\mathrm{BD}$

Bank's supply chain practices and performance can further be improved through the assimilation, acceptance, and routinization of large data and resources such as information sharing, connectivity, and corporate commitment (Li, Fan, Lee, \& Chang, 2015). Focusing to address technological changes through the integration of these capabilities require banks' awareness of changes in environment and support from top management to combat E\&S risks. Banks have the obligation of utilizing and sustainably managing resources due to changes in market conditions and depletion of resources (United Nations Report, 2019).

Practicing these environmental management activities is supported through the greening of SCM, technology, and innovation, which should be encouraged by policy- 
makers and bank commitment. GI is a key strategic factor as it patronages sustainable development by using technologically innovative methods of energy conservation, waste recycling, and pollution prevention (Chang, 2011). The innovative practices (internal supply chain management) and its implementation are executed by collaborating with all supply chain partners of the banks (Chithambaranathan, Subramanian, Gunasekaran, \& Palaniappan, 2015). To achieve a sustainability supporting system, it is mandatory for all the suppliers of the banks to embrace environmental requirements for both customers and the banks. When suppliers continue to meet environmental requirements, green product innovation increases (Chiou, Chan, Lettice, \& Chung, 2011), which directly improves banks' competitive advantage and environmental performance (EP). Additionally, GSCM emerges as an environment preservation strategy, which collectively lifts EP of the bank and the entire supply chain. Consequently, it is predicted that:

H2. Bank's commitment positively impacts internal and external GSCM practices.

It is challenging for policymakers to generate and collect large volume of data as it requires strategic decision-making to extract the hidden and actual value (Chen \& Zhang, 2014). In an industrialized world where the market is unpredictable, it becomes challenging for the financial institutions to mitigate the right mix of technology (Salman, 2019). BD provides a ground-breaking opportunity for businesses, particularly in the service sector, where it increases productivity and financial performance (FP). Usage of BDAs in banks SCM context can be understood by a framework developed by Nguyen, Li, Spiegler, Ieromonachou and Lin (2018), as SCM is one of the key areas, which can affect a business that relies on large data analytics. Operational excellence and competitive advantage by banks can be achieved through the transformation from regular SCM to practicing GSCM. Based on the proceeding discussion it is posited that:

$\mathrm{H} 3$. The assimilation of $\mathrm{BD}$ through acceptance and routinization positively impacts on internal GSCM practices of the bank

Past studies indicate the association of several challenges with large volume of data as it is highly diverse and comes in high velocity, which is challenging for environmental theories and methods. Therefore, these theories become inapplicable due to the lack of accuracy and consistency (Song, Cen, Zheng, Fisher, Liang, \& Wang, 2017). BDAs positively influence information sharing, customer service management, customer demand management, and environmental management (Yang, Burger, Peters, Cruz, \& Steinberg, 2016). Moreover, previous studies indicate the capability of BDAs to reduce carbon emission (Zhao, Liu, Zhang, \& Huang, 2017) and increase the economic performance (Akter, Wamba, Gunasekaran, Dubey, \& Childe, 2016) and E\&S performance (Song, Cen, Zheng, Fisher, Liang, \& Wang, 2017). The regulatory bodies in financial institutions are continuously struggling to handle the dynamic shift in the market due to disruption of digital currencies (Salman, 2019). Furthermore, climate change creates vibrant opportunities for business organizations, and the way of doing business can be transformed through BDAs provided organizations continuously focus on sustainable environmental performance. Hence, it is predicted that:

H4. The assimilation of BD through acceptance and routinization positively impacts on the environmental and bank performance.

The adoption of green banking is the result of green innovations, which help the banks to achieve sustainable development goals such as conservation of energy, recycling of waste, and prevention of pollution (Masukujjaman, Siwar, Mahmud, \& Alam, 2017). Socially responsible financial institutions focus on the creation of jobs, rural and urban development, and resolving environmental challenges (Cervelló-Royo, Guijarro, \& Martinez-Gomez, 2019). The success of implementing green innovation at the workplace relies on corporate commitment and environmental ethics. Corporations design its GSCM practices in a way that decreases the footprints on the environment and enhance its operational performance. Additionally, past studies discovered that banks' GSCM and environmental disclosure have a direct impact on their environmental performance (WWF Sustainable Finance Report, 2017). These findings lead to the development of aligning and leveraging GSCM for disclosure practice effectiveness to enhance banks' environmental and financial performance (EFP). Hence, we argue that green SCM practices, such as interaction with customers and green purchasing on banks' EP, and green collaboration with suppliers and green innovation processes may enhance banks' competitiveness in the dynamic market. In lieu of this argument, it is hypothesized that:

H5. Internal and external GSCM practices positively influence environmental and bank performance.

While assimilating BD, there are several GSCM, internal and external supply partners, and sustainable practices challenges. Intriguingly, firms having specialized and skilled CEOs experience better performance (Cheng, Li, Lin, \& Chih, 2020). Moreover, these challenges are manageable 
through GHR practices and corporate commitment, which focus to improve environmental and organizational performance (Gunasekaran, Papadopoulos, Dubey, Wamba, Childe, \& Hazen, 2017). The study has found that organizational internal motivations have a direct impact on GSCM, direct relationship with corporate commitment and influence while implementing green standards (Igbudu, Garanti, \& Popoola, 2019). Moreover, green technology, policies and practices of going green, and EP are positively related. Hence, it is inferred that practicing GHR facilitates the adoption of green management, green technologies, and green management. We posit that practicing green HR not only facilitate the bank's sustainability, but also enhance its financial performance. Accordingly, it is predicted that:

H6. Green HR practices and training impact $\mathrm{BD}$ acceptance on routinization, GSC collaboration on internal GSCM, and internal GSCM on environmental and bank's performance.

These hypotheses and the arguments discussed above are outlined in the conceptual model of this study in Figure 1.

\section{Research Methodology}

\subsection{Survey and Data Collection}

This study analyzes the impact of large data driven strategy on banks' sustainable performance through internal operations that depict SCs. Additionally, the current study further examines the relationship between BD assimilation, internal and external GSCM practices, banks' sustainable performance (environmental and financial), and the impact of policymakers' commitment. Moreover, the impact of mediating variables such as GHR, particularly green training and practices, on the above variables is also measured in our study. The hypotheses and the predicted relationships were measured through a self-administrated survey questionnaire.

\subsection{Questionnaire Content}

The questionnaire comprised two sections, namely, A and B. Section A contained the demographics of the respondents; section B consisted of 11 variables that collectively contain 50 items. These items were self-constructed and were adjusted accordingly to achieve the objectives of this study. Bank commitment (BCMT) contained five items adopted from Liang, Saraf, Hu and Xue (2007), big data acceptance (BDACP) comprised three items extracted from Hazen, Overstreet and Cegielski (2012), big data routinization (BDRT) had five items adopted from Hazen, Overstreet and Cegielski (2012), big data assimilation (BDAS) contained four items borrowed from Hazen, Overstreet and Cegielski (2012), and Liang, Saraf, $\mathrm{Hu}$ and Xue (2007), and green supply chain collaboration (GSCC) consisted of four items adopted from Chiou, Chan, Lettice and Chung (2011). Green process innovation (GPCINV) consisted of five items adopted from Chiou, Chan, Lettice and Chung (2011), green product innovation (GPINV) contained four items adopted

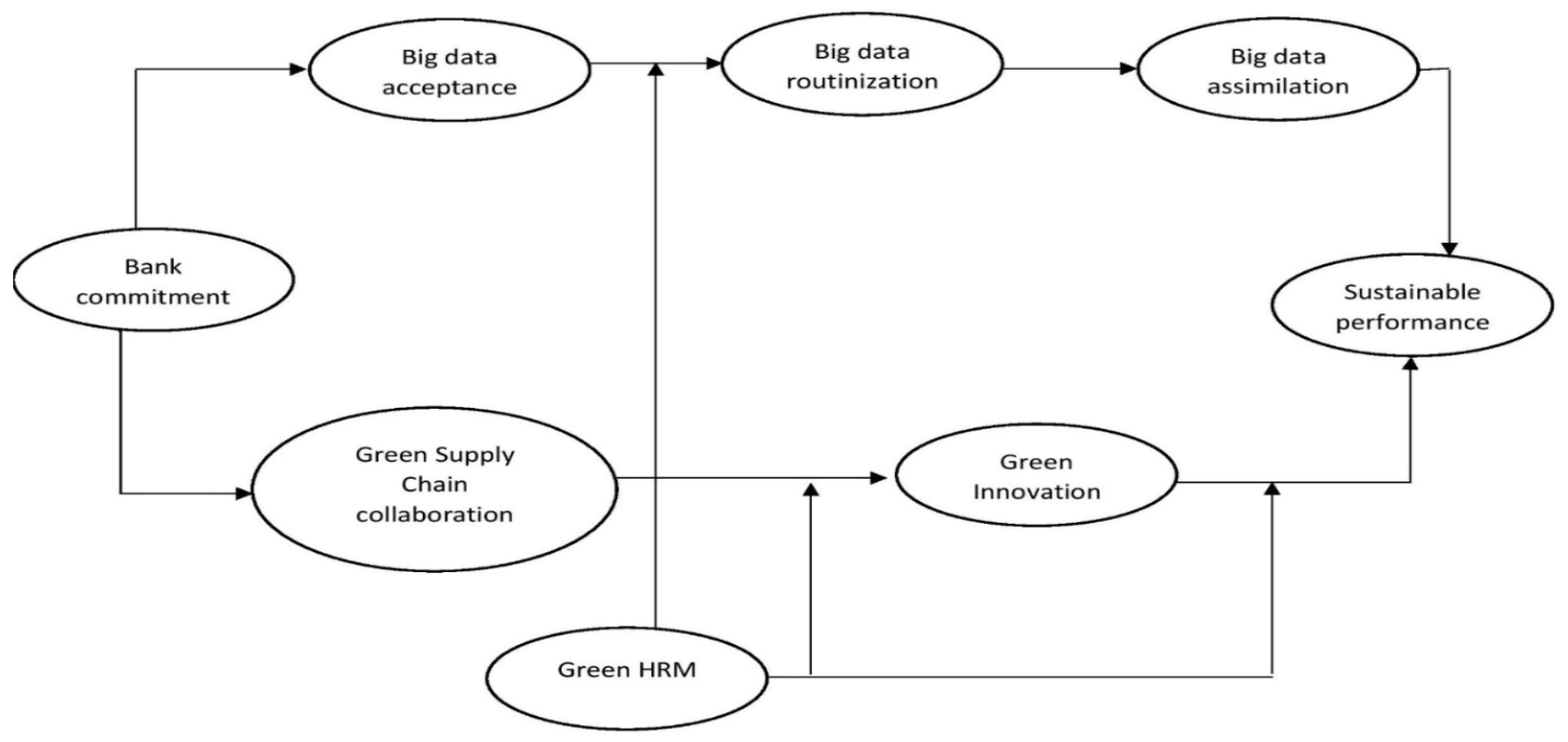

Figure 1: Conceptual model of the research 
from Chiou, Chan, Lettice and Chung (2011), while green HR training (GHRTR) contained five items adopted from De Kok, Uhlaner and Thurik (2006). Similarly, green HR practices (GHRPR) contained five items adopted from Astrachan and Kolenko (1994), environmental performance (EP) was measured by six items adopted from Lin, Tan and Geng (2013), and the bank performance (BP) was measured through four items adopted from Lin, Tan and Geng (2013). The respondents were provided with a 5-point Likert scale (strongly disagree $=1$ to strongly agree $=5$ ) to respond to the items listed in section B.

\subsection{Questionnaire Administration}

Before circulation of the actual questionnaire, a pilot test was conducted through the feedback from three university professors and three industry experts to enhance the relevance and accuracy of the content of the questionnaire. The target population consisted of employees and managers employed in the banks having prior experience of using BDAs to adopt sustainable practices. Since the targeted population is known to the researchers, a non-random convenience sampling technique is rendered as the most reliable method for data collection purpose.

The respondents were formally approached and requested to participate in the online survey. A total of 378 potential respondents in 35 banks located in six different ASEAN countries (Singapore, Malaysia, Indonesia, Philippines, Vietnam, and Thailand) were requested to respond to the questionnaire. The respondents returned 338 completed questionnaires, indicating a return rate of $89.94 \%$. However, for the actual analysis, 319 samples were considered suitable as 19 samples were not completely filled. We contacted 15 participants to check for non-response bias and requested participants to disclose the reasons for not participating in the survey. We discovered that the main reason for not participating was the low understanding of the variables used in our study. The demographic values are considered to perform the chi-square test to compare between early respondents (the participants who returned the questioners within the first two weeks of receipt of the questionnaire) and late respondents (unable to return the questionnaires within 14-21 days). We do not observe any significant difference between early and late respondents, which confirms that our study is free from issues of non-response bias.

\subsection{Data Analysis}

The collected data is analysed through partial least squares structural equation modeling (PLS-SEM) using PLS3 to test the hypotheses of this study. This technique is more reliable compared to traditional covariancebased SEM as it requires a large sample size (Kline,
2012). Moreover, it is a reliable technique as it accurately estimates the complicated hierarchical models containing the assumptions from the soft model. The past studies have vigorously applied this method to test the complex models of BDAs in the business domain (El-Kassar \& Singh, 2019; Papadopoulos, Gunasekaran, Dubey, Altay, Childe, \& Wamba, 2017a, b; Wamba, Gunasekaran, Akter, Rameshwar, Stephen, \& Childe, 2017).

PLS-SEM is a two-stage process, validation of outer model and estimation of inner model path coefficients. The outer model validation is developed by estimating the reliability of coefficients constructs along with their convergent discriminant validity. After measuring the outer model validation, we inserted the inner model to measure the path coefficients. The bootstrap method was used to analyse the significance of findings. The mediating role of green HRM practices and training was analysed through multi-group analysis, which was accomplished by performing cluster analysis, a method used for the segregation of the respondents' banks based on their HR practices. The cluster analysis helps in grouping these banks into clusters as proposed by Kamakura and Wedel (2000). The cluster analysis was also used to observe the groups following the characteristics of the latent variables. Furthermore, a multigroup analysis was performed as suggested by El-Kassar and Singh (2019), to estimate the significant difference in the path coefficients across the groups.

\section{Results and Findings}

\subsection{Analysis of Outer Model}

All the latent variables were analyzed using reflective scheme whereby the model analysis was estimated by unstandardized full data set. The estimation of convergent and the discriminant validity of the latent constructs were performed by the PLS-SEM method using Smart PLS3. The test results of the factor loadings are presented in Figure 2, which indicates that the value of each item is greater than $(0.70)$, the minimum threshold value of acceptable convergent validity. Therefore, the adopted variables determine the significant variance in all the observed variables (Huland, 1999). Additionally, the bootstrap method further confirmed the significance of the factor loading as the values loading show the significance at 0.01 level.

The results of reliability and average variance extracted (AVE) are presented in Table 1. The reliability test was performed to estimate Cronbach's alpha coefficients and scale composite reliability. The results show that the Cronbach's alpha coefficient value of each construct is greater than the minimum cut-off value $(0.70)$, it suggested that each construct of our study was unidimensional, reflective properties, and contains high-scale reliability. 
Qaisar ALI, Asma SALMAN, Hakimah YAACOB, Zaki ZAINI, Rose ABDULLAH I

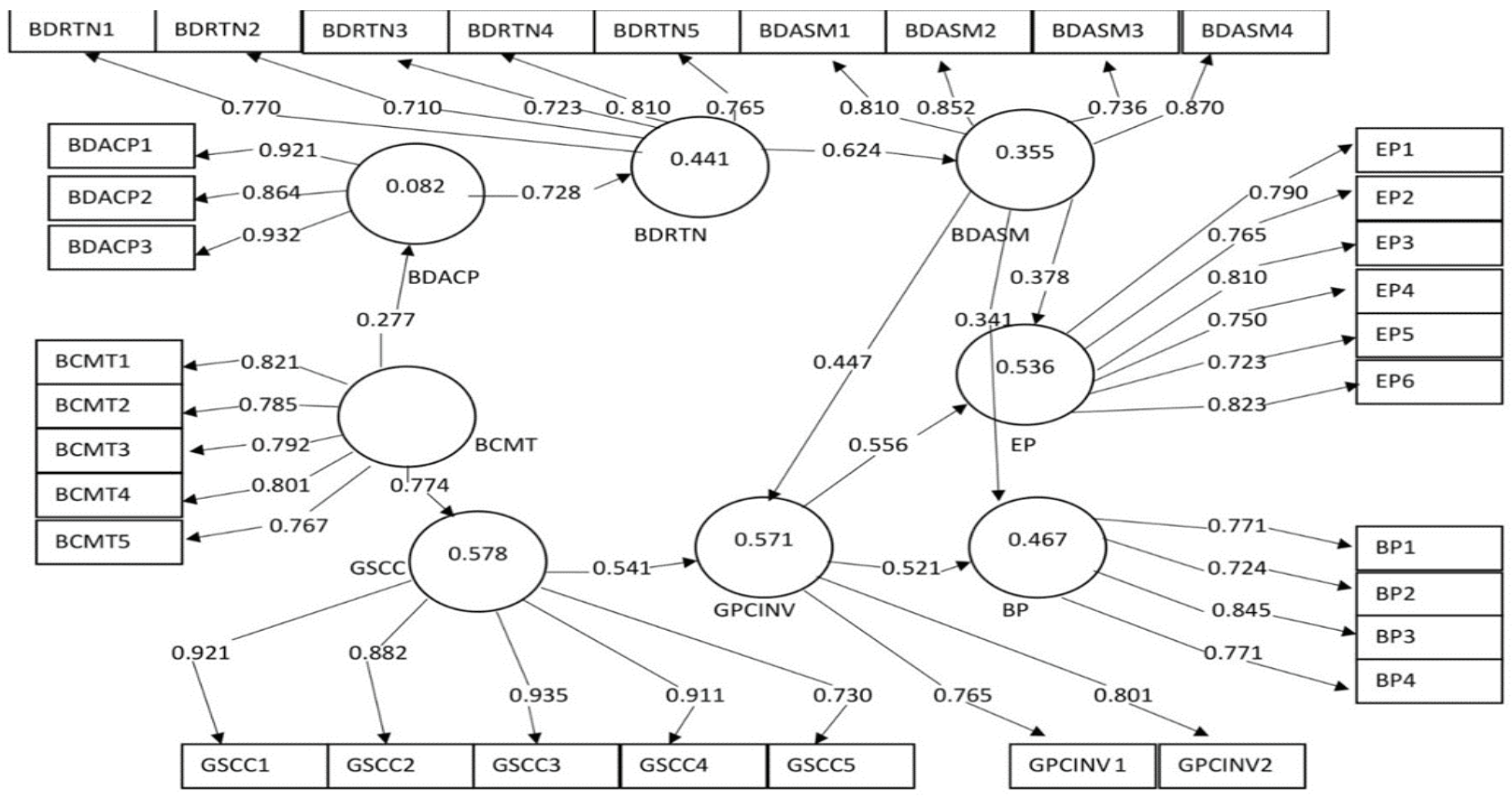

Figure 2: PLS-SEM results of proposed model

Table 1: Reliability and validity of constructs

\begin{tabular}{|l|c|c|c|}
\hline \multicolumn{1}{|c|}{ Variables } & Cronbach's alpha & Composite reliability & Average variance extracted (AVE) \\
\hline BDACP & 0.625 & 0.814 & 0.568 \\
\hline BDASM & 0.723 & 0.865 & 0.589 \\
\hline BDRTN & 0.742 & 0.855 & 0.607 \\
\hline BCMT & 0.826 & 0.901 & 0.670 \\
\hline EP & 0.816 & 0.865 & 0.689 \\
\hline GRNINV & 0.782 & 0.889 & 0.655 \\
\hline
\end{tabular}

AVE values of each construct are $>0.50$ which confirms the discriminant validity as the AVE of each variable is greater than the variance of other variables in our study (Fornell \& Larcker, 1981). Table 2 indicates the results of discriminant validity which depicts that the diagonal values are greater compared to any of the values in the consistent columns and rows

\subsection{Inner Model Analysis}

Prior to inner model analysis, it is mandatory to estimate R2 values. The output suggested that the model explains significant part of variance of the constructs and satisfies the suggested criteria (Chin, 1998); and the suggested model has satisfactory nomological validity (Chin, 1998). Next, we calculated inner model path coefficients, which was done by calculating the path coefficients among the constructs to measure the structural model. The coefficients of inner model path and outer loadings were measured by performing bootstrap method (Davison \& Hinkley, 1997). The measures of path coefficients are presented in Table 3. The findings specify that all path coefficients are significant as the $t$ statistics values from bootstrap method are greater than 2 . This also supports our hypotheses H1 to H5.

\subsection{Cluster Analysis}

Hypothesis H6 was tested through cluster analysis, which groups the banks according to relative green HR management practices and training. The multi-group analysis was also 
Table 2: Discriminant validity results

\begin{tabular}{|l|c|c|c|c|c|c|c|c|}
\hline Variables & BDACP & BDASM & BDRTN & BCMT & EP & GPCINV & GSCC & BP \\
\hline BDACP & 0.752 & & & & & & \\
\hline BDASM & 0.432 & 0.787 & & & & & \\
\hline BDRTN & 0.678 & 0.475 & 0.776 & & & & \\
\hline BCMT & 0.365 & 0.464 & 0.400 & 0.789 & & & \\
\hline EP & 0.331 & 0.390 & 0.441 & 0.552 & 0.811 & & & \\
\hline GRNINV & 0.220 & 0.430 & 0.322 & 0.537 & 0.723 & 0.923 & & \\
\hline GSCC & 0.310 & 0.329 & 0.450 & 0.652 & 0.597 & 0.771 & 0.880 & \\
\hline BP & 0.287 & 0.467 & 0.356 & 0.580 & 0.432 & 0.561 & 0.670 & 0.890 \\
\hline
\end{tabular}

Table 3. Results of inner path coefficients

\begin{tabular}{|c|c|c|c|c|}
\hline Direct effect & Original sample & Mean & SD & t statistics \\
\hline $\mathrm{BDACP} \longrightarrow \mathrm{BDRTN}$ & 0.518 & 0.531 & 0.0261 & 16.259 \\
\hline $\mathrm{BDASM} \longrightarrow \mathrm{EP}$ & 0.378 & 0.367 & 0.040 & 6.165 \\
\hline BDASM $\longrightarrow$ GRNINV & 0.469 & 0.469 & 0.062 & 8.187 \\
\hline BDASM - & 0.364 & 0.363 & 0.087 & 3.443 \\
\hline$\rightarrow$ BDASM & 0.404 & 0.405 & 0.044 & 8.390 \\
\hline$\Rightarrow$ BDACP & 0.399 & 0.403 & 0.051 & 5.733 \\
\hline$\rightarrow$ GSCC & 0.796 & 0.798 & 0.032 & 15.747 \\
\hline GRNINV & 0.557 & 0.663 & 0.052 & 8.012 \\
\hline GRNINV & 0.390 & 0.382 & 0.042 & 5.872 \\
\hline GSCC $\longrightarrow$ GRNINV & 0.523 & 0.521 & 0.031 & 7.128 \\
\hline \multicolumn{5}{|l|}{ Direct Effect } \\
\hline BDASM - & 0.153 & 0.155 & 0.002 & 3.972 \\
\hline $\mathrm{BDASM}=$ & 0.167 & 0.171 & 0.004 & 4.132 \\
\hline BDRTN = & 0.316 & 0.322 & 0.081 & 7.113 \\
\hline$\Rightarrow$ GRNINV & 0.227 & 0.237 & 0.034 & 5.790 \\
\hline BDRTN - & 0.211 & 0.211 & 0.325 & 5.112 \\
\hline$\Rightarrow$ BDASM & 0.123 & 0.126 & 0.004 & 3.523 \\
\hline $\mathrm{BCMT}=$ & 0.143 & 0.150 & 0.082 & 3.211 \\
\hline$\Rightarrow$ GRNINV & 0.902 & 0.897 & 0.061 & 8.234 \\
\hline $\mathrm{BCMT} \longrightarrow \mathrm{BP}$ & 0.975 & 0.963 & 0.780 & 9.170 \\
\hline GSCC & 0.183 & 0.192 & 0.135 & 8.321 \\
\hline $\mathrm{GSCC} \longrightarrow \mathrm{BP}$ & 0.220 & 0.234 & 0.412 & 6.600 \\
\hline
\end{tabular}


performed to estimate whether there exists significance among path coefficients of the groups. We employed K-means clustering technique by specifying clusters while cluster seeds were randomly selected. The observations were allocated for each cluster by using similarity principles. The testing clusters vary (for example, two, three and four) for estimation of the suitable cluster to be adopted. The output clustered the banks into two groups, 13 banks labelled "low green HR training" and the remaining 22 banks were clustered as the high "green HR training".

After cluster analysis, the next step was to estimate path coefficients of the inner model for each group for comparison of the findings. It was observed that two direct path coefficients (green innovation to EP, and to bank performance) had a significant difference, hence H6 was supported. The path coefficients results are reported in Table 4. The results show that, for indirect path coefficients, no significant difference exists. We performed again the test for GHR management practices. Once again 21 banks loaded in the cluster indicating banks with 'high GHR management practices' and 14 banks represented the cluster of banks having "low green HR management practices". Additionally, multi group analysis was performed, however, for path coefficients no significant difference was detected.

\section{Discussion and Conclusion}

\subsection{Banks' Sustainable Performance through BDAs}

The results of outer model (Figure 2) determine that all the suggested constructs, namely, bank commitment, GI process,
GSC collaboration, and GHRM collectively contribute to the sustainable performance and the overall performance of ASEAN banks through acceptance, assimilation, and routinization of BDAs. These findings reinforce the findings of previous studies by Masukujjaman, Siwar, Mahmud and Alam (2017), and Iqbal, Nisha, Rifat and Panda (2018), which showed that the adoption of green banking practices by the banks creates environmental, social, and corporate benefits for the banks. The findings of this study (Table 1) suggest that the ASEAN banks can pick up the low hanging fruits of sustainable performance and development of SCs by harnessing effective analytics of BD. These findings are compatible with the studies by McAfee (2012), Constantiou and Kallinikos (2015), Manyika, Chui, Brown, Bughin, Dobbs and Roxburgh (2011), suggesting that BDAs potentially contribute to organizational decision-making, achieve competitive advantage, and help firms to become a frontier of innovation, competition, and productivity.

\subsection{Factors Influence the Usage of BDAs to Enhance SCs of Banks}

The results (Table 3) of this study indicate that banks' commitment impacts on the acceptance, assimilation, and routinization of $\mathrm{BD}$, which, alternatively improves the sustainable and operational performance of the organization. These findings reinforce the findings by Marr (2017) and Allen (2005), which showed that the organizations committed towards proper data monitoring of their clients can achieve operational efficiency and sustainability. Additionally, our findings (Table 3) illustrate that banks' commitment further impacts on internal and external GSCM practices, which

Table 4: Results of multi-group analysis

\begin{tabular}{|l|c|c|c|c|c|c|c|}
\hline Effect & $\begin{array}{c}\text { Path Coef } \\
\text { (high) }\end{array}$ & $\begin{array}{c}\text { Path Coef } \\
\text { (low) }\end{array}$ & $\begin{array}{c}\text { t values } \\
\text { (high HRT) }\end{array}$ & $\begin{array}{c}\text { t-Values } \\
\text { (Low HRT) }\end{array}$ & $\begin{array}{c}\text { p-Values } \\
\text { (High HRT) }\end{array}$ & $\begin{array}{c}\text { p-Values } \\
\text { (Low HRT) }\end{array}$ & $\begin{array}{c}\text { p-Value } \\
\text { (High vs } \\
\text { Low) }\end{array}$ \\
\hline BDACP $\longrightarrow$ BDRTN & 0.468 & 0.582 & 10.616 & 11.451 & 0.001 & 0.000 & 0.824 \\
\hline BDASM $\longrightarrow$ EP & 0.283 & 0.312 & 3.333 & 3.213 & 0.012 & 0.000 & 0.843 \\
\hline BDASM $\longrightarrow$ GRNINV & 0.387 & 0.531 & 5.622 & 6.194 & 0.002 & 0.000 & 0.864 \\
\hline $\mathrm{BDASM} \longrightarrow \mathrm{BP}$ & 0.257 & 0.269 & 2.651 & 3.744 & 0.000 & 0.001 & 0.965 \\
\hline $\mathrm{BDRTN} \longrightarrow \mathrm{BDASM}$ & 0.368 & 0.412 & 4.567 & 5.318 & 0.002 & 0.000 & 0.687 \\
\hline $\mathrm{BCMT} \longrightarrow \mathrm{BDACP}$ & 0.276 & 0.337 & 3.246 & 4.523 & 0.011 & 0.002 & $0 / 772$ \\
\hline $\mathrm{BCMT} \longrightarrow \mathrm{GSCC}$ & 0.545 & 0.611 & 12.203 & 11.773 & 0.021 & 0.000 & 0.516 \\
\hline $\mathrm{GRNINV} \longrightarrow \mathrm{EP}$ & 0.565 & 0.602 & 7.696 & 3.272 & 0.011 & 0.002 & 0.232 \\
\hline $\mathrm{GRNINV} \longrightarrow \mathrm{BP}$ & 0.433 & 0.513 & 7.767 & 3.315 & 0.001 & 0.032 & 0.198 \\
\hline $\mathrm{GSCC} \longrightarrow \mathrm{GRNINV}$ & 0.621 & 0.754 & 12.345 & 11.876 & 0.021 & 0.001 & 0.911 \\
\hline
\end{tabular}


alternatively yields financial and environmental gains for the banks. These results are compatible with studies by Gunasekaran, Papadopoulos, Dubey, Wamba, Childe and Hazen (2017), Dubey, Gunasekaran, Childe, Papadopoulos, Luo and Wamba (2017), and Papadopoulos, Gunasekaran, Dubey and Wamba $(2017 \mathrm{a}, \mathrm{b})$ on BDAs that suggest organizations boost their environmental and financial performance through their commitment towards BDAs.

\subsection{Influence of Green Innovation on Banks' Sustainability and Performance}

This study found (Table 4) the existence of a significant difference in the impact of GI on banks' financial and EP between 'high' and 'low' green HR training of employees. This study found that banks' practising GI represent better environmental and economic performance as the employees of these banks have received high levels of advance GHR training. This is justified by the fact that, organizations that encourage their employees toward green creativity achieve better environmental management (Bos-Nehles, Renkema and Janssen, 2017. This finding is consistent with studies by El-Kassar and Singh (2019); Gunasekaran, Papadopoulos, Dubey, Wamba, Childe, Hazen, and Akter (2017); and Jabbour and de Sousa Jabbour (2016).

Lastly, we found (Table 4) that internal and external GSCM has a positive impact on banks' environmental and financial performance (EFP). This implies that ASEAN banks can contribute to reducing the environmental impact through their operations provided they develop and implement GSCM practices, which ultimately will result in increased financial gains. These finding echoes the previous studies by De Sousa Jabbour, Vazquez-Brust, Jabbour, and Latan (2017) and Vanalle, Ganga, Filho, and Lucato (2017), which show that leveraging advance knowledge of GSCM practices achieves better economic and environmental performance for the organizations.

Overall, it was found that ASEAN banks are leveraging BDAs to enhance their SCs through continuous commitment, green innovation process, GSCM collaboration, and GHRM practices. In addition, our study found that banks are also leveraging BDAs to gain economic and environmental gains. Moreover, green innovations, green training, and GSCM collaboration have a significant impact on developing SCs and achieve financial gains for the banks. Our study has supported all the hypotheses H1 to H6.

This study aims to examine how ASEAN banks are driven to develop SCs through their commitment, BDT integration, GHRM practices, and GSCM, and in turn analyzes how these banks leverage these constructs to improve their economics and EP. Additionally, the current study has measured the impacts of GHRM practices on the integration of BDT with banks' operational processes to strengthen the relationship between internal and external GSCM practices and their influence on banks' sustainable performance. Our findings are robust and have several theoretical and practical implications, which are discussed below.

\subsection{Theoretical Implications}

This study has manifold theoretical contributions; firstly, it contributes to advance the knowledge on BDT and its influence to boost banks' EFP. Secondly, it advances the knowledge pertaining to the role of GHR training to optimize the impact of GI on banks' EFP. Lastly, this study adds significant knowledge to leverage GSCM practices to augment the EFP of banks.

\subsection{Practical Implications}

Firstly, it is suggested for the banks adopt an exclusive and functional process to integrate BDT into their strategic and operational architecture to maximise their FP. Moreover, banks need to focus on utilizing relevant BDT to tap the diverse opportunities pertinent to business.

Secondly, banks require the support and the commitment of top management in terms of practising GSCM and GHRM to enhance their SCs. Alternatively, persistent commitment to internal GSCM practices and GHR training help banks stay competitive in a dynamic financial market. Moreover, it is suggested for the banks integrate formal environmental policy at corporate and operational levels, so that internal and external GSCM, GT, and GI continue to amplify SCs and FP.

Lastly, based on the findings of this study it is suggested for the banks cope effectively with technological challenges to assimilate $\mathrm{BD}$, as these challenges may negatively impact the banks when they focus on external GSCM and sustainable practices. The potential business opportunities and obstacles offered through sustainability and $\mathrm{BD}$ are manageable provided banks' top management is committed to implement GHR practices especially encouraging the employees toward green creativity, as it will facilitate the adoption of green management, green technologies, and green operation, which are the essentials of enhancing EFP.

\subsection{Limitations and Suggestions for Future Research}

As with any other study, there are certain limitations associated with this study. The first limitation was the research design, which was a single source survey questionnaire as 
a source of primary data. It is suggested that future studies may consider using other methods of data collection, such as interviews along with the survey questionnaire. The second limitation is the use of quantitative data and limited construct to analyze the linkage between bank commitment, big data analytics, GSCM practices, GHRM practices, GI, and SCs. Future studies may consider using an extended research framework and consider employing mix methods to analyse the data. Lastly, our study has collected data from a limited number of banks and all ASEAN regions were not included due to financial and time constraints. Hence, future studies may consider extending the sample size and collection of data from all the major banks situated in other ASEAN countries to truly depict the SCs of ASEAN banks.

\section{References}

Acharya, A., Singh, S. K., Pereira, V., \& Singh, P. (2018). Big data, knowledge co-creation, and decision making in fashion industry. International Journal of Information Management, 42(4), 90-101. https://doi.org/10.1016/j.ijinfomgt.2018.06.008

Akter, S., Wamba, S. F., Gunasekaran, A., Dubey, R., \& Childe, S. J. (2016). How to improve firm performance using big data analytics capability and business strategy alignment? International Journal of Production Economics, 182, 113-131. https://doi.org/10.1016/j.ijpe.2016.08.018

Allam, Z. (2020). Theology and Urban Sustainability. Springer Briefs in Geography. https://doi.org/10.1007/978-3-03029673-5

Allen, P. (2005). How Disney Saves Energy and Operating Costs. HPAC Engineering. Retrieved February 10, 2020, from: http:// www.hpac.com/building-controls/how-disney-saves-energyand-operating-costs

Amui, L. B. L., Jabbour, C. J. C., de Sousa Jabbour, A. B. L., \& Kannan, D. (2017). Sustainability as a dynamic organizational capability: a systematic review and a future agenda toward a sustainable transition. Journal of Cleaner Production, 142, 308-322. https://doi.org/10.1016/j.jclepro.2016.07.3

Argote, L. (2012). Organizational Learning: Creating, Retaining and Transferring Knowledge. Springer Science \& Business Media.

Astrachan, J. H., \& Kolenko, T. A. (1994). A neglected factor explaining family business success: human resource practices. Family Business Review, 7(3), 251-262. https://doi.org/10.1111/ j.1741-6248.1994.00251.x

Bos-Nehles, A., Renkema, M., \& Janssen, M. (2017). HRM and innovative work behaviour: A systematic literature review. Personnel review, 46(7), 1228-1253. https://doi.org/10.1108/ PR-09-2016-0257

Carvalho, H., Govindan, K., Azevedo, S. G., \& Cruz-Machado, V. (2017). Modelling green and lean supply chains: an ecoefficiency perspective Resources. Conservation and Recycling, 120(2), 75-87. https://doi.org/10.1016/j.resconrec.2016.09.025
Chang, C. H. (2011). The influence of corporate environmental ethics on competitive advantage: the mediation role of green innovation. Journal of Business Ethics, 104(3), 361-370.

Chen, C. P., \& Zhang, C. Y. (2014). Data-intensive applications, challenges, techniques and technologies: a survey on Big Data. Information Sciences, 275, 314-347. https://doi.org/10.1016/j. ins.2014.01.015

Cheng, T. Y., Li, Y. Q., Lin, Y. E., \& Chih, H. H. (2020). Does the Fit of Managerial Ability with Firm Strategy Matters on Firm Performance. Journal of Asian Finance, Economics and Business, 7(4), 9-19. https://doi.org/10.13106/jafeb.2020. vol7.9

Chin, W. (1998). Issues and opinion on structural equation modeling. MIS Quarterly, 22(1), 7-16.

Chiou, T. Y., Chan, H. K., Lettice, F., \& Chung, S. H. (2011). The influence of greening the suppliers and green innovation on environmental performance and competitive advantage in Taiwan. Transportation Research Part E: Logistics and Transportation Review, 47(6), 822-836. https://doi. org/10.1016/j.tre.2011.05.016

Chithambaranathan, P., Subramanian, N., Gunasekaran, A., \& Palaniappan, P. K. (2015). Service supply chain environmental performance evaluation using grey based hybrid MCDM approach. International Journal of Production Economics, 166, 163-176. https://doi.org/10.1016/j.ijpe.2015.01.002

Constantiou, I. D., \& Kallinikos, J. (2015). New games, new rules: big data and the changing context of strategy. Journal of Information Technology, 30(1), 44-57. https://doi.org/10.1057/ jit.2014.17

Corbett, C. J. (2018). How Sustainable Is Big Data? Production and Operations Management, 27(9), 1685-1695. https://doi. org/10.1111/poms.12837

Davison, A. C., \& Hinkley, D. V. (1997). Bootstrap Methods and Their Application. Cambridge University Press, Cambridge.

De Kok, J. M., Uhlaner, L. M., \& Thurik, A. R. (2006). Professional HRM practices in family owned-managed enterprises. Journal of Small Business Management, 44(3), 441-460. https://doi.org/ 10.1111/j.1540-627X.2006.00181.x

De Sousa Jabbour, A. B. L., Vazquez-Brust, D., Jabbour, C. J. C., \& Latan, H. (2017). Green supply chain practices and environmental performance in Brazil: survey, case studies, and implications for B2B. Industrial Marketing Management, 66, 13-28. https://doi.org/10.1016/j.indmarman.2017.05.003

Dubey, R., Gunasekaran, A., Childe, S. J., Papadopoulos, T., Luo, Z., Wamba, S. F., \& Roubaud, D. (2017). Can big data and predictive analytics improve social and ES? Technology Forecasting \&Social Change [First online]. https:// doi. org/10.1016/j.techfore.2017.06.020.

El-Kassar, A., \& Singh, S. K. (2019). Green innovation and organizational performance: the influence of big data and the moderating role of management commitment and HR practices. Technological Forecasting and Social Change, 144, 483-498. https://doi.org/10.1016/j.techfore.2017.12.016 
Fornell, C. G. \& Larcker, D. F. (1981). Evaluating structural equation models with unobservable variables and measurement error. Journal of Marketing Research, 18(1), 39-50.

Govindan, K., Sarkis, J., Jabbour, C. J. C., Zhu, Q., \& Geng, Y. (2014). Eco-efficiency based green supply chain management: current status and opportunities. European Journal of Operational Research, 233(2), 293-298. https://doi. org/10.1016/j.ejor.2013.10.058

Gunasekaran, A., Papadopoulos, T., Dubey, R., Wamba, S. F., Childe, S. J., Hazen, B., \& Akter, S. (2017). Big data and predictive analytics for supply chain and organizational performance. Journal of Business Research, 70(1), 308-317. https://doi.org/10.1016/j.jbusres.2016.08.004

Hampton, S. E., Strasser, C. A., Tewksbury, J. J., Gram, W. K., Budden, A. E., Batcheller, A. L., \& Porter, J. H. (2013). Big data and the future of ecology. Frontier in the Ecology and Environment, 11(3), 156-162. https://doi.org/10.1890/120103

Hazen, B. T., Overstreet, R. E., \& Cegielski, C. G. (2012). Supply chain innovation diffusion: going beyond adoption. International Journal of Logistics Management, 23(1), 119134. https://doi.org/ 10.1108/09574091211226957

Hulland, J. (1999). Use of partial least squares (PLS) in strategic management research: a review of four recent studies. Strategic Management Journal, 20(2), 195-204.

IBM Global Business Services Report. (2013). Analytics: The real-world use of big data in financial services. Retrieved January 10, 2020, from https://www.ibm.com/downloads/cas/ E4BWZ1Y

Igbudu, G. I. N., Garanti Z., \& and Popoola, T. (2019). Assessing the Relevance of Green Banking Practice on Bank Loyalty: The Mediating Effect of Green Image and Bank Trust. Sustainability, 11, 4651. https://doi.org/10.3390/su11174651

International Environment Agency. (2015). Southeast Asia Energy Outlook 2015. Retrieved January 23, 2020, from www.iea. org/publications/freepublications/publication/WEO2015 SouthEastAsia.pdf

Iqbal, M., Nisha, N., Rifat, A., \& Panda, P. (2018). Exploring Client Perceptions and Intentions in Emerging Economies: The Case of Green Banking Technology. International Journal of Asian Business and Information Management, 9(3), 14-34. https:// doi.org/10.4018/IJABIM.2018070102

Jabbour, C. J. C., \& de Sousa Jabbour, A. B. L. (2016). Green human resource management and green supply chain management: linking two emerging agendas. Journal of Cleaner Production, 112(3), 1824-1833. https://doi.org/10.1016/j. jclepro.2015.01.052

Jackson, S., Renwick, D., Jabbour, C. J. C., \& Muller-Camen, M. (2011). State-of-the-Art and future directions for green human resource management. German Journal of Human Resource Management, 25(2), 99-116. https://doi. org/10.1177/239700221102500203

Jun, S. (2019). Bayesian structural time series and regression modeling for sustainable technology management.
Sustainability, 11(18), 4945. https://doi.org/10.3390/ su11184945

Kamakura, W. A., \& Wedel, M. (2000). Factor analysis and missing data. Journal of Marketing Research, 37(4), 490-498.

Kline, R. (2012). Beyond Significance Testing. American Psychological Association, Washington, DC.

Li, G., Fan, H., Lee, P. C. K., \& Chang, T. C. E. (2015). Joint supply chain risk management: An agency and collaboration perspective. International Journal of Production Economics, 164, 83-94. https://doi.org/10.1016/j.ijpe.2015.02.021

Liang, H., Saraf, N., Hu, Q., \& Xue, Y. (2007). Assimilation of enterprise systems: the effect of institutional pressures and the mediating role of top management. MIS Quarterly, 31(1), 5987.

Lin, R. J., Tan, K. H., \& Geng, Y. (2013). Market demand, green product innovation, and firm performance: evidence from Vietnam motorcycle industry. Journal Cleaner Production, 40, 101-107. https://doi.org/ 10.1016/j.jclepro.2012.01.001

Manyika,J., Chui, M., Brown, B., Bughin, J., Dobbs, R., Roxburgh, C., \& Byers, A. H. (2011). Big Data: The Next Frontier for Innovation, Competition, and Productivity. Published by Mckinsey Digital. Retrieved January 24, 2020, from https:// www.mckinsey.com/businessfunctions/mckinsey-digital/ourinsights/big-data-the-next-frontier-for-innovation

Marr, B. (2017). IoT And Big Data at Caterpillar: How Predictive Maintenance Saves Millions of Dollars. Retrieved January 20, 2020, from https://www.forbes. $\mathrm{com} / \mathrm{sites} /$ bernardmarr/2017/02/07/iot-and-big-data-atcaterpillar-how-predictivemaintenance-saves-millions-ofdollars/\#203abf737240

Masukujjaman, M., Siwar, C., Mahmud, M. R., \& Alam, S. S. (2017). Bankers' perception of Green Banking: Learning from the experience of Islamic banks in Bangladesh. Malaysian Journal of Society and Space, 12(2), 144-153.

McAfee, A., Brynjolfsson, E., \& Davenport, T. H. (2012). Big data: the management revolution. Harvard Business Review, 90(10), 68,128

Mckinsey \& Company Global Banking Report. (2018). Smart Analytics for Banks. Retrieved January 07, 2020, from https://www.mckinsey.com/ /media/McKinsey/Industries/ Financial\%20Services/Our\%20Insights/Smarter\%20 analytics\%20for\%20banks/Smarter-analytics-for-banks.ashx

Mikalef, P., Pappas, I. O., Krogstie, J., \& Giannakos, M. (2018). Big data analytics capabilities: a systematic literature review and research agenda. Information Systems and e-Business Management volume, 16, 547-5781. https://doi.org/10.1007/ s10257-017-0362-y

Mikalef, P., Krogstie, J., Pappas, I. O., \& Pavlou, P. (2019). Exploring the relationship between big data analytics capability and competitive performance: The mediating roles of dynamic and operational capabilities. Information \& Management, 57(2), 103-169. https://doi.org/10.1016/j.im.2019.05.004 
Qaisar ALI, Asma SALMAN, Hakimah YAACOB, Zaki ZAINI, Rose ABDULLAH I

Nguyen, T., Li, Z. H. O. U., Spiegler, V., Ieromonachou, P., \& Lin, Y. (2018). Big data analytics in supply chain management: a stateof-the-art literature review. Computer \& Operations Research 98, 254-264. https://doi.org/10.1016/j.cor.2017.07.004

Nguyen, T. L. H., Nguyen, T. T. H., Nguyen, T. T. H., Le, T. H. A., \& Nguyen, V. C. (2020). The Determinants of Environmental Information Disclosure in Vietnam Listed Companies. Journal of Asian Finance, Economics and Business, 7(2), 21-31 https:// doi.org/10.13106/jafeb.2020.vol7.no2.21

Nurlanova, N. K., Akedil, K., Omarov, A. K., \& Satpayeva, Z.T. (2020). Methodological Approaches to Estimation of Economic Growth and Sustainable Development: Kazakhstan's Experience. Journal of Asian Finance, Economics and Business, 7(4), 317-324. https://doi.org/10.13106/jafeb.2020. vol7.no4.317

Papadopoulos, T., Gunasekaran, A., Dubey, R., Altay, N., Childe, S. J., \& Wamba, F. S. (2017a). The role of big data in explaining disaster resilience in supply chains for sustainability. Journal of Cleaner Production, 142, 1108-1118. https://doi.org/10.1016/j. jclepro.2016.03.059

Papadopoulos, T., Gunasekaran, A., Dubey, R., \& Wamba, F. S. (2017b). Big data and analytics in operations and supply chain management: managerial aspects and practical challenges. Production Planning and Control, 28(11-12), 873-876. https:// doi.org/10.1080/09537287.2017.1336795

Pereze, A., \& Bosque, I. R. D. (2015). The Formation of Customer CSR Perceptions in the Banking Sector: The Role of Coherence, Altruism, Expertise and Trustworthiness. International Journal of Business and Society, 16(1), 75-94. https://doi.org/10.33736/ ijbs.555.2015

Salman, A. (2019). Digital Currencies and the Power Shift in the Economy: IEREK Interdisciplinary Series for Sustainable Development. Proceedings of the 1st American University in the Emirates International Research Conference-Dubai, UAE 2017. 978(3)030-01661-6. https://doi.org/10.1007/978-3-03001662-3_14

Seles, B. M. R. P., de Sousa Jabbour, A. B. L., Jabbour, C. J. C., de Camargo Fiorini, P., Mohd- Yusoff, Y., \& Thome, A. M. T. (2018). Business opportunities and challenges as the two sides of the climate change: corporate responses and potential implications for big data management towards a low carbon society. Journal of Cleaner Production, 189, 763-774. https:// doi.org/10.1016/j.jclepro.2018.04.113

Singh, S. K., \& El-Kassar, A. N. (2019). Role of big data analytics in developing sustainable capabilities. Journal of Cleaner Production, 213(2), 164-1273. https://doi.org/10.1016/j. jclepro.2018.12.199

Song, M., Cen, L., Zheng, Z., Fisher, R., Liang, X., Wang, Y., \& Huisingh, D. (2017). How would big data support societal development and ES? Insights and practices. Journal of
Cleaner Production, 142(2), 489-500. https://doi.org/10.1016/j. jclepro.2016.10.091

Teece, D. J., Pisano, G., \& Shuen, A. (1997). Dynamic capabilities and strategic management. Strategic Management Journal, 18(7), 509-533.

The ASEAN Post.(2020). Big data is revolutionising microfinancing. Retrieved February 14, 2020, from https://theaseanpost.com/ article/big-data-revolutionising-microfinancing

UNEP Finance Initiative. (2016). Guide to Banking and Sustainability Edition II. Retrieved February 04, 2020, from https://www.unepfi.org/wordpress/wp-content/ uploads/2017/06/CONSOLIDATED-BANKING-GUIDEMAY-17-WEB.pdf

United Nations Report. (2019). Financing for Sustainable Development. Retrieved January 14, 2020, from https:// v2.sdgfin.org/wpcontent/uploads/2019/04/financing-forsustainable-developmentreport.pdf

Vanalle, R. M., Ganga, G. M. D., Filho, G. M., \& Lucato, W. C. (2017). Green supply chain management: an investigation of pressures, practices, and performance within the Brazilian automotive supply chain. Journal of Cleaner Production, 151, 250-259. https://doi.org/ 10.1016/j.jclepro.2017.03.066

Wamba, S. F., Gunasekaran, A., Akter, S., Rameshwar, S. J. R., Stephen, D., \& Childe, J. (2017). Big data analytics and firm performance: Effects of dynamic capabilities. Journal of Business Research, 70, 356-365. https://doi.org/10.1016/j. jbusres.2016.08.009

World Economic Forum. (2019). Banking on sustainability - what's next? Retrieved January 22, 2020, from https:/www.weforum. org/agenda/2019/09/how-banks-can-be-more-sustainable/

WWF Sustainable Finance Report. (2017). Sustainable Banking in ASEAN: Addressing Asean's Forests, Landscapes, Climate, Water, Societies. Retrieved January 12, 2020, from https:// www.wwf.fr/sites/default/files/doc-2017 10/1710_rapport sustainable_finance.pdf

Yang, E., Burger, J., Peters, M., Cruz, B., \& Steinberg, H. (2016). Customer Service Management \& Hofstede's Cultural Dimensions in Australia, Brazil, China, Germany, Japan, Norway, And the USA. In Allied Academies International Conference. Academy of Organizational Culture, Communications and Conflict. Proceedings; Arden, 21(1), 6265.

Zhao, R., Liu, Y., Zhang, N., \& Huang, T. (2017). An optimization model for green supply chain management by using a big data analytic approach. Journal of Cleaner Production, 142, 10851097. https://doi.org/10.1016/j.jclepro.2016.03.006

Zimmermann, S. (2019). Same but Different: How and Why Banks Approach Sustainability. Sustainability, 11(8), 2267. https:// doi.org10.3390/su11082267 